\title{
RECENZJE
}

\author{
ARLETA SUWALSKA \\ Wydział Nauk o Wychowaniu \\ Uniwersytet Łódzki \\ ORCID ID: https://orcid.org/oooo-ooo3-0713-8451
}

Forum Pedagogiczne

$9(2019) 2$, cz. 2

Wpłynęło: 07.10.2019

Zatwierdzono do druku: 20.11.2019

DOI: $10.21697 / \mathrm{fp} .2019 .2 .46$

\section{Multidimensionality of Contemporary Polish Pedagogy}

[Z. Kwieciński, B. Śliwerski (red.) (2019). Pedagogika. Podręcznik akademicki. Warszawa: Wydawnictwo Naukowe PWN, 1127 s.]

This precisely and accurately updated and fully expanded edition of the bestseller Pedagogika covers the scope of basic knowledge, contemporary pedagogical thoughts and trends. This masterpiece reveals pedagogical approaches that correspond to the global changes in the current world. This outstanding book consists of 50 chapters. The book is recommended as a coursebook for teachers who seek indispensable knowledge about learning and education, presented from different perspectives and dimensions, both theoretically and practically.

The first part of this exceptional book contains 23 chapers. It starts with chapter one Pedagogika jako nauka (Education as science) in which Bogusław Śliwerski discusses concepts and views of pedagogy (education) as theoretical and practical science. The author not only develops pluralistic concept of pedagogy and its ideas but also presents disputes between theories in pedagogy. Śliwerski presents a pluralistic concept of pedagogy, which in the period of the Third Republic of Poland became something obvious and natural. Moreover, the author writes about the crack and radical separation of Polish humanities from monistic, ideologically degraded socialist pedagogy. In addition, he claims that this state will be a lasting achievement of of socio-political transformation.

The second chapter, Edukacja w galaktyce znaczeń (Education in a galaxy of meaning), written by a co-editor, Zbigniew Kwieciński, provides definitions, development phases in education and education barriers for humanity. Moreover, Kwieciński exposes a presentation of discourses, ideologies, paradigms and typologies by Theodore Brameld and William T. O’Neill.

Book's unprecedented approach is especially visible in Historia oświaty $i$ wychowania (History of schooling and education) remarkably prepared by Stefan Wołoszyn, an outstanding master of this educational subdiscipline. Moreover, the chapter Pedagogika pozytywizmu warszawskiego (Pedagogy of Warsaw positivism) prepared by Jacek Kulbaka describes the socio-political situation 
in Poland in the second half of the nineteenth century. It presents the genesis of positivism and thoughts of leading representatives.

The fifth chapter Pedagogika narodowosocjalistyczna (National Socialist pedagogy) written by Adam Fijałkowski and the sixth chapter Polski nurt krytyki totalitaryzmów (Polish criticism of totalitarianism) written by Janina Kostkiewicz extend the readers' knowledge in the field of education (Bildung) in the Third Reich (1933-1945) and criticism of Bolshevism, Italian Fascism and German Nazism. The next chapter, written by J. Kostkiewicz describes Polskie koncepcje i kierunki rozwoju pedagogiki kultury (1918-1939) (Polish concepts and directions of development of pedagogy of culture (1918-1939)). The following pages of this book written by Teresa Hejnicka-Bezwińska broadens the reader's knowledge about Pedagogika socjalistyczna (Socialist pedagogy).

Bogusław Śliwerski in the chapter Teorie wychowania (Theories of Education) conducts intricate theoretical considerations on the theory of education. Śliwerski takes into account relations between theory of education and general pedagogy. In this edition he presents contemporary theories of education (general didactics) with typology of variations in didactics. Readers will find information about Pedagogika wczesnej edukacji (Pedagogy of early-childhood education) perfectly written by Dorota Klus-Stańska.

Pedagogika porównawcza (Comparative pedagogy) was written and explained by Renata Nowakowska-Siuta. The author mentions the most significant topics undertaken in comparative studies. There are revealed such competences as "the ability to communicate in mother tongue and foreign languages, mathematical, scientific and technical competences, creativity and entrepreneurship, social, civic and IT competences with culture awareness and cultural expression." (p. 302)

The chapter Filozofia edukacji (Philosophy of Education) was authored by Rafał Godon who explores the specificity of this pedagogy in the light of philosophical reflection and the methodological aspect of the philosophy of education. The book demonstrates Pedagogika religii (The Religion Pedagogy) and Pedagogika kultury (Pedagogy of Culture) with mutli-dimensional concepts, beginnings and ideas. Both chapters have been created by Bogusław Milerski. Pedagogika społeczna (Social Pedagogy) chapter written by Barbara Smolińska-Theiss and Wiesław Theiss reveals beginnings of social pedagogy, sources, categories and asks questions about its future. Kultura popularna jako czynnik socjalizacji (Popular Culture as a factor of socialization) authored by Zbyszko Melosik fortifies such meanings as: consumption, instant culture, fast pace of life, culture of body and success. Agnieszka Cybal-Michalska writes about Pedagogika młodzieży (Youth pedagogy) as a subject of pedagogical research.

The chapter Andragogika (Andragogy) by Mieczysław Malewski explains the principles of adult education. Moreover, Jacek Pyżalski in the chapter Cyfrowa pedagogika medialna (Digital Media Pedagogy) provides such phenomena as interactivity, digitality and the new media environment. Pedagogika specjalna 
(Special Pedagogy) chapter written by Iwona Chrzanowska draws up the paradigmatic change in defining disability. The author proposes age divisions such as childhood, youth, adulthood and old age of people with disabilities. The chapter Empiryczne badania ilościowe $w$ pedagogice (Empirical quantitative research in pedagogy) prepared by Krzysztof Rubacha equips readers with knowledge on research schemes, methods and quantitative empirical studies. Moreover, the next chapter written by Danuta Urbaniak-Zając increases the reader's knowledge about Empiryczne badania jakościowe w pedagogice (Empirical qualitative research in Education). This chapter arranges the nature of qualitative research, its preparation, research procedures and summary.

The second part of this book contains 15 chapters which include contemporary pedagogical concepts. This is an outstanding work that includes such subsets of Pedagogy as Pedagogika instrumentalna (Instrumental Pedagogy) by T. HejnickaBezwińska, Pedagogika personalistyczna (Personalistic pedagogy) by Marian Nowak, Pedagogika egzystencjalna (Existential Pedagogy) by Janusz Tarnowski, Pedagogika pragmatyzmu (Pedagogy of Pragmatism), Pedagogika postmodernizmu (Pedagogy of postmodernism) by Zbyszko Melosik, Pedagogy of anarchistyczna (Anarchist pedagogy), Pedagogika negatywna (Negative Pedagogy) by B. Śliwerski, Pedagogika krytyczna (Critical pedagogy), Pedagogika międzykulturowa (Intercultural pedagogy) by Tomasz Szkudlarek, Pedagogika emancypacyjna (Emancipation pedagogy), Pedagogika rekonstrukcjonizmu społecznego (Pedagogy of social reconstructionism) by Hanna Kostyło, Pedagogika Gestalt (Gestalt pedagogy) by Wiktor Żłobicki, Pedagogika ekologiczna (Ecological pedagogy) by Agnieszka Gromkowska-Melosik and Utopizm pedagogiczny (Pedagogical utopism) by Rafał Włodarczyk.

The last part consists of 12 chapters which are entitled Pedagogika Reform Edukacyjnych (Pedagogy of educational reforms). The author of three chapters is B. Śliwerski, who discusses the features of Pedagogika waldorfska (Waldorf pedagogy), Pedagogika planu daltońskiego (Pedagogy of the Dalton Plan) and Reformy oświaty $w$ Polsce (Reforms of education in Poland). He pays attention to types of educational reforms in Poland, the scope of educational change, the quality of reforms and to the reforms' implementation.

Wiesław Jamrożek describes Pedagogika "nowego wychowania" (Pedagogy of progressivism) in which the author pays readers' attention to genesis and development of progressivism in Education. Małgorzata Miksza presents Pedagogika Montessori (Maria Montessori's concept of education) and puts emphasis on the role of the teacher in preparing the teaching environment. Z. Melosik reveals the pros and cons of Education in chapter Edukacja a stratyfikacja społeczna (Education and social stratification). The author considers concepts to solve problems with access to higher education. The chapter Szkolne środowisko uczenia się (School learning environment) written by Mariola Chomczyńska-Rubacha associates the organizational culture of the school with the language and patterns of communication in the classroom. 
The definitions, scope and shaping of school culture constitute the chapter Kultura szkoly (School culture) written by Inetta Nowosad. The author describes school efficiency and presents the features of positive school culture. The chapter Proces kształcenia (Educational process) by Bogusława D. Gołębniak discusses the school curriculum, exams and assessment, teaching and learning in the classroom. The chapter Nauczyciel (Teacher) authored by Joanna Madalińska-Michalak presents teacher studies as a subject, including considerations about teacher's duties and professional development. The chapter Agresja i przemoc w szkole (Aggression and violence at school) written by Janusz Szurzykiewicz explains terminological findings and dynamics of aggression and violence at school.

Concepts of education portrayed in this new edition of Pedagogika include involvement of various organizations like the government and institutions that work with families, peers, kindergartens, schools, universities, local communities, associations, organizations, etc. Furthermore, Pedagogika is essential reading for teachers, new academics and anyone who is interested in the educational research. The text is supported by a wealth of pictures, charts, tasks to solve and references. 